\title{
Patient management and clinical outcomes in non-traumatic small bowel perforations
}

\section{Travmatik olmayan ince barsak perforasyonlarında hasta yönetimi ve klinik sonuçlar}

Ahmet Türkoğlu ${ }^{1}$, Burak Veli Ülger ${ }^{1}$, Ömer Uslukaya ${ }^{1}$, Abdullah Oğuz $^{1}$, Yılmaz Zengin², IIlhan Taş ${ }^{3}$, Mesut Gül ${ }^{1}$, Zülfü Arıkanoğlu ${ }^{1}$

\section{ABSTRACT}

Objective: The aim of this study was to report our management and outcomes of patients who underwent surgery with the diagnosis of non-traumatic small bowel perforation.

Methods: The records of 30 patients who underwent surgery for non-traumatic small bowel perforation between 2005 and 2013 were examined. Age, gender, complaints, duration of symptoms, comorbid disease(s), perforation location, length of stay in hospital, etiology, surgical treatment, morbidity, and mortality data were recorded. Patients were divided into two groups, survivors and nonsurvivors, and their features were compared.

Results: The mean age of the patients was $51.3 \pm 19.9$ years. Signs of peritoneal irritation were present in $22(73.3 \%)$ patients. In surgical exploration, generalized purulent peritonitis was observed in $14(46.6 \%)$ patients, while localized peritonitis was observed in the others. Bowel resection was performed in $27(90 \%)$ patients, while primary suture was performed in only $3(10 \%)$ patients. A diverting ileostomy was performed in $18(60 \%)$ patients. Mortality was observed in $9(30 \%)$ patients. Duration of the symptoms and multiple perforations were significantly higher in non-survivors.

Conclusion: A delay in diagnosis and presence of multiple perforations are the most important causes of mortality. Every effort should be made to avoid delay in diagnosis; however, once the diagnosis is delayed, especially in patients with multiple perforations, extensive surgery such as bowel resection and ileostomy should not be avoided. J Clin Exp Invest 2015; 6 (2): 130-134

Key words: Non-Traumatic, small bowel perforation, diagnosis, management

\section{ÖZET}

Amaç: Bu çalışmanın amacı, travmatik olmayan ince barsak perforasyonu nedeniyle ameliyat edilen hasta yönetimimizi ve sonuçlarını sunmaktır.

Yöntemler: Kliniğimizde 2005 ve 2013 arasında travmatik olmayan ince bağırsak perforasyonu nedeniyle ameliyat edilen 30 hastanın kayıtları incelendi. Hastalara ait yaş, cinsiyet, şikayetler, belirtilerin süresi, eşlik eden hastalık(lar), perforasyon yeri, hastanede kalış süresi, etyoloji, cerrahi tedavi, morbidite ve mortalite verileri kaydedildi. Hastalar yaşayanlar ve ölenler olmak üzere iki gruba ayrıldı ve grupların çeşitli özellikleri karşılaştırıldı.

Bulgular: Hastaların yaş ortalaması $51,3 \pm 19,9$ yıl idi. Periton irritasyonu bulguları 22 (\% 73,3) hastada vardı. Eksplorasyonda 14 (\% 46,6) hastada yaygın pürülan peritonit gözlenirken, diğerlerinde lokalize peritonit mevcuttu. Primer sütürasyon sadece $3(\% 10)$ hastaya uygulanırken, barsak rezeksiyonu 27 (\%90) hastaya uygulandı. Saptırıcı ileostomi 18 (\%60) hastaya uygulandı. Mortalite 9 (\%30) hastada gözlendi. Semptom süresi ve çoklu perforasyon varlığı mortalite gelişen hastalarda anlamlı derecede yüksek bulundu.

Sonuç: Tanıda gecikme ve çoklu perforasyon varlığı mortalitenin en önemli nedenleridir. Tanıda gecikmeyi önlemek için her türlü çaba harcanmalıdır; ancak, eğer tanı gecikmişse, özellikle çoklu perforasyonu olan hastalarda bağırsak rezeksiyonu ve/veya ileostomi gibi geniş cerrahi prosedürlerden kaçınılmamalıdır.

Anahtar kelimeler: Travmatik olmayan, ince bağırsak delinmesi, tanı, yönetim

\footnotetext{
${ }^{1}$ Dicle Üniversitesi Tıp Fakültesi Genel Cerrahi Anabilim Dalı, Diyarbakır, Türkiye

${ }^{2}$ Dicle Üniversitesi Tıp Fakültesi Acil Tıp Anabilim Dalı, Diyarbakır, Türkiye

${ }^{3}$ Cizre Devlet Hastanesi Genel Cerrahi, Cizre, Şırnak, Türkiye
}

Correspondence: Ahmet Türkoğlu,

Dicle Üniversitesi Tıp Fakültesi Genel Cerrahi Anabilim Dalı, Diyarbakır, Türkiye Email: ahmetturkoglu04@hotmail.com

Received: 07.04.2015, Accepted: 23.04.2015

Copyright @ JCEI / Journal of Clinical and Experimental Investigations 2015, All rights reserved 


\section{INTRODUCTION}

Non-traumatic small bowel perforation, a rare cause of acute abdomen, is a condition that can lead to fatal complications unless timely intervention occurs [1]. Many reasons may be counted in the etiology of non-traumatic small bowel perforation. Although infectious causes, especially typhoid and tuberculosis are forefront in developing countries, Crohn's disease and malignancies are more common in developed countries [1,2].

Presence of recurrent abdominal pain episodes due to underlying disease and having non-specific clinical and laboratory findings may lead to a delay in the preoperative diagnosis. Although radiological imaging procedures are helpful in diagnosis, the early diagnosis rate is low, and the majority of cases are diagnosed during laparotomy. Primary repair and resection-anastomosis with or without ileostomy are the operative procedures that depend on the cause of the disease and the extent of peritoneal contamination [3]. Despite advances in surgical techniques and improvement in intensive care conditions, mortality of non-traumatic small bowel perforation is still high and can be up to $42 \%[1,4]$.

This study aimed to report our management and outcomes of the patients who underwent surgery for the diagnosis of non-traumatic small bowel perforation.

\section{METHODS}

We retrospectively examined the records of patients who underwent surgery for non-traumatic small bowel perforation between January 2005 and March 2013. The patients with intestinal perforations due to trauma, mesenteric ischemia and obstruction or strangulation because of hernia, volvulus or intraabdominal adhesions, and peptic ulcer perforations of the duodenum were excluded from the study.

History of the patients, physical examination findings, laboratory data, imaging, and operative reports were examined. Age, gender, complaints, duration of symptoms, comorbid disease(s), perforation location, length of stay in hospital, etiology, surgical treatment, morbidity, and mortality data were recorded. All patients were divided into two groups, survivors and non-survivors, and their features were compared.

Preoperative routine complete blood count and biochemical tests were performed in all patients. Initial imaging modalities were pulmonary and ab- dominal x-ray and abdominal ultrasound (USG). Abdominal computed tomography (CT) was performed in patients in whom direct abdominal X-ray and USG examination were normal. Patients who were thought to have acute abdomen according to physical examination, laboratory, and radiological findings underwent surgery after initial resuscitation. A prophylactic broad-spectrum antibiotic therapy was started for all cases preoperatively. Perforation was managed by either primary suturing or resection and anastomosis with or without ileostomy. All patients received postoperative antibiotic therapy as prophylactic or therapeutic according to the results of cultures. Tissue biopsy was performed in all patients and a segment of diseased tissue or lymph node was sent for culture for mycobacterium in suspected cases.

\section{RESULTS}

The mean age of the 30 patients diagnosed with non-traumatic small bowel perforation was $51.3 \pm$ 19.9 years. Of the cases, $13(43.3 \%)$ were female and $17(56.7 \%)$ were male. Abdominal pain was the most common complaint in all cases, and other symptoms were nausea, vomiting, abdominal distention, and constipation (Table 1). In the history of the patients, three were receiving treatment for a diagnosis of lymphoma. Two had Crohn's disease, four had chronic obstructive pulmonary disease, three had cardiac problems, and two patients had diabetes mellitus.

Table 1. Signs and symptoms in patients with small bowel tumors

\begin{tabular}{lc}
\hline Sign/Symptom & $\mathbf{n}(\%)$ \\
\hline Abdominal pain & $30(100)$ \\
Nausea/vomiting & $23(76.6)$ \\
Signs of peritoneal irritation & $22(73.3)$ \\
Abdominal distention & $18(60)$ \\
Constipation & $3(10)$ \\
\hline
\end{tabular}

While abdominal tenderness was present in all patients, signs of peritoneal irritation were present in $22(73.3 \%)$ patients. The other eight patients had moderate localized or generalized tenderness but relatively soft abdomen (Table 1 ). Leukocytosis was not present in all patients, as only 9 had leukocytosis and 3 had neutropenia. Electrolyte imbalance was present in $11(36.6 \%)$ patients. Positive serologic test for typhoid fever was found in 2 (6.6\%) patients. Intraperitoneal free air was observed in 
21 patients, and air-fluid levels were observed in 8 patients in abdominal X-ray. Free fluid or abscess formation was observed in $23(76.6 \%)$ patients in abdominal USG. CT scan was performed in 17 $(56.6 \%)$ patients who could not be diagnosed by other methods or to determine the perforation site (Table 2).

Table 2. Clinical features of patients

\begin{tabular}{lc}
\hline Feature & $\mathbf{n ~ ( \% )}$ \\
\hline Leukocytosis & $9(30)$ \\
Neutropenia & $3(10)$ \\
Electrolyte imbalance & $11(36.6)$ \\
Positive serologic test for typhoid & $2(6.6)$ \\
X-Ray & $21(70)$ \\
Free air & $8(26.6)$ \\
Air-fluid levels & $23(76.6)$ \\
Free fluid or abscess on US & $17(56.6)$ \\
CT scan &
\end{tabular}

US: Ultrasound, CT: Computerized tomography

In intraoperative exploration, jejunal perforation was detected in $6(20 \%)$ patients and ileal perforation was detected in $24(80 \%)$ patients. Multiple perforations were detected in $9(30 \%)$ patients. A generalized purulent peritonitis was observed in 14 (46.6\%) patients while localized peritonitis was observed in $16(46.6 \%)$ patients. Primary suture was performed in $3(10 \%)$ patients while small bowel resection was performed in $27(90 \%)$ patients. A diverting ileostomy was performed in addition to bowel resection in $18(60 \%)$ patients with generalized peritonitis, tuberculosis or malignancy. A Bogota bag was performed in a patient with a high intraabdominal pressure (Table 3).

Etiologic investigation revealed that a considerable number of cases $(n=14)$ had nonspecific features on histological examination. Six of these had nonspecific ulcers and eight had nonspecific inflammation. Amongst the cases where a definitive diagnosis could be given, most were diagnosed with intestinal tuberculosis, typhoid, lymphoma, adenocarcinoma, Crohn's disease, and gangrene (Table 4).
Table 3. Intraoperative finding and operation types

\begin{tabular}{lc}
\hline Feature & $\mathbf{n}(\%)$ \\
\hline Jejunal perforation & $6(20)$ \\
lleal perforation & $24(80)$ \\
\hline Perforation count & \\
Single & $21(70)$ \\
Multiple & $9(30)$ \\
\hline Generalized purulent peritonitis & $14(46.6)$ \\
\hline Surgery type & \\
Primary suture & $3(10)$ \\
Bowel resection & $27(90)$ \\
lleostomy & $17(56.7)$ \\
\hline
\end{tabular}

Table 4. Etiology of small intestine perforations

\begin{tabular}{lc}
\hline Diagnosis & $\mathbf{n}(\%)$ \\
\hline Nonspecific features & $14(46.6)$ \\
Tuberculosis & $2(6.7)$ \\
Typhoid & $2(6.7)$ \\
NHL & $3(10)$ \\
Adenocarcinoma & $3(10)$ \\
Intussusception on polyp & $2(6.7)$ \\
Gangrene & $2(6.7)$ \\
Choriocarcinoma & $1(3.3)$ \\
Crohn's disease & $1(3.3)$ \\
Appendix tumor & $1(3.3)$ \\
Foreign body & $1(3.3)$ \\
\hline
\end{tabular}

Mortality was observed in $9(30 \%)$ patients. Duration of the symptoms was significantly higher in non-survivors (median 11 hours; range 3-15) than in survivors (median 4 hours; range 1-13). The number of patients with multiple perforations was significantly higher in non-survivors $(n=6 ; 66.7 \%)$ than in survivors $(n=3 ; 14.2 \%)$. Though generalized peritonitis was observed at a higher rate in non-survivors $(n=7 ; 77.8 \%)$ in comparison with survivors $(n=7$; $33.3 \%$ ), it was not statistically significant. The major complications were wound infection, pneumonia, ARDS, sepsis, pleural effusion, enterocutaneous fistula or leak, intra-abdominal abscesses, and pulmonary emboli. Among these, ARDS and sepsis were statistically associated with high mortality rate. The features of the surviving and non-surviving patients are shown in Table 5. 
Table 5. Features of surviving and nonsurviving patients

\begin{tabular}{lccc}
\hline Risk factor & $\begin{array}{c}\text { Non-survivors } \\
(\mathbf{n = 9})\end{array}$ & $\begin{array}{c}\text { Survivors } \\
(\mathbf{n = 2 1})\end{array}$ & p value \\
\hline Age, median years (ranges) & $51(20-84)$ & $55(20-88)$ & 0.44 \\
Duration of Symptoms, median hours (ranges) & $11(3-15)$ & $4(1-13)$ & 0.003 \\
White Blood Cell Count Median, (Range) & $8740 / \mathrm{mm}^{3}$ & $8120 / \mathrm{mm}^{3}$ & 0.72 \\
& $(1120-15900)$ & $(3150-14200)$ & 0.015 \\
Multiple perforations, (n) & 6 & 3 & 0.066 \\
Generalized peritonitis, (n) & 7 & 7 & \\
\hline lleostomy, (n) & & & 0.37 \\
Yes & 7 & 11 & \\
No & 2 & 8 & 0.93 \\
\hline Complications (n) & & 2 & 0.176 \\
Wound infection & 4 & 0 & 0.001 \\
Pneumonia & 3 & 2 & 0.005 \\
ARDS & 3 & 4 & 0.322 \\
Sepsis & 6 & 5 & 0.69 \\
Leak from operated area & 4 & & \\
Intraabdominal abscess & 6 & & \\
\hline
\end{tabular}

\section{DISCUSSION}

Non-traumatic small bowel perforation is uncommon but can have a high morbidity or be fatal. Therefore, it continues to be an important problem in surgical clinical practice. Infectious causes including tuberculosis and typhoid fever are the most common causes in developing countries [1], though non-infectious causes like malignancy and Crohn's disease are more common in developed countries [2]. Deep ulcers, abscess formation, single or complex fistulas may develop in Crohn's disease, but free spontaneous perforation into the peritoneal cavity is quite rare [5]. Typhoid perforations are usually characterized by a single perforation, history of travel to an endemic region, and intermittent fever. Histopathological examination is important for differential diagnosis, but in some cases it may be non-specific [1]. Adenocarcinoma and lymphomas are the most common histopathological types of malignancies. More than half of the perforations in lymphomas develop after chemotherapy is initiated. Granulomatous inflammation in the histopathological examination is an important sign of tuberculosis $[5,6]$.

The clinical presentation in non-traumatic perforation of the small intestine may be non-specific $[1,3]$. The abdominal examination of eight of our patients revealed moderate localized or generalized tenderness but relatively soft abdomen. The diagnosis is mainly clinical, supported by the radiological finding of free gas under the diaphragm
[7]. In seven of our patients, chest X-ray and USG were normal. Even the CT scan was normal in one patient. Laboratory investigations were not helpful in all cases. Leukocytosis was present in only nine patients.

Early diagnosis is a very important factor for morbidity and mortality. A delay in surgical treatment worsens electrolyte imbalance and systemic toxemia due to rapid progression of peritonitis [8]. The reasons for delayed treatment in non-traumatic small bowel perforations are probably due to its being a rare disease, presence of recurrent abdominal pain episodes because of underlying disease, the nonspecific symptoms, and difficulties in diagnosis. Early surgical intervention has been shown to reduce morbidity and mortality $[8,9]$.

Etiology and the degree of peritoneal contamination should be considered in the decision of which surgical procedure to repair the perforated segments. Primary suturation is recommended in patients with single perforation and no generalized peritonitis, though resection and anastomosis is preferred in patients with multiple perforations $[1,8]$. Because the prognosis is associated with the degree of peritonitis, ileostomy is preferred in patients with generalized peritonitis [8]. Because the degree of peritonitis is usually advanced due to the delay in diagnosis, ileostomy is required in most patients. It should be noted that anastomosis leakage rates might be high in patients with tuberculosis or lymphoma on whom primary closure or resection-anastomosis without ileostomy were performed. Delayed 
primary closure of the skin incision helps to reduce the wound infection rate $[3,8]$. In the present study, ileostomy was performed in $17(56.6 \%)$ patients who had a high risk of leakage because of generalized peritonitis or diseases such as tuberculosis and malignancies. Primary closure was performed in only three $(10 \%)$ patients with localized peritonitis. No leakage was observed in these patients. On the other hand, a resection and anastomosis without ileostomy was performed in $10(33.3 \%)$ patients with localized peritonitis and anastomotic leakage was observed in four of these. The cause of the small number of primary anastomosis might be because it was performed in highly selected patients.

The overall mortality in patients with non-traumatic small bowel perforation has been reported to be between $16.6 \%$ and $45 \%$. Delayed operation, primary closure of perforations, presence of multiple perforations, generalized peritonitis, and leak from the surgical area are reported to be important factors causing high mortality $[3,10]$. Duration of symptoms was significantly longer in our patients in whom postoperative mortality was seen. Because primary closure was performed in only three selected patients, no mortality was found in these patients. Multiple perforations were also observed more commonly in patients who died in our study. Although the rate of presence of generalized peritonitis was higher in non-surviving patients, it was not statistically significant. We also found a higher mortality in patients with ARDS and sepsis as postoperative complications. Although ileostomy is preferred, especially in patients at high risk because of generalized peritonitis or multiple perforations, the mortality rate was not higher in our patients with ileostomy than the others. This situation suggests that ileostomy may decrease the mortality rate in patients with high risk.

\section{CONCLUSION}

A delay in diagnosis and multiple perforations are the most important causes of mortality and a high level of suspicion is required for early diagnosis. Therefore, especially in patients with a history of chronic diseases such as Crohn's disease, typhoid, or abdominal tuberculosis, the diagnosis should not be delayed by connecting the complaints of the patients to the previous attacks of the chronic diseases. Although early diagnosis may enable the avoidance of extensive procedures, once the diagnosis is delayed, especially in patients with multiple perforations, extensive surgery like bowel resection and/or ileostomy should not avoided in order to prevent fistula or sepsis to prevent morbidity and mortality. Because systemic complications are common in these patients, they must be treated in advanced centers involving improved intensive care units.

\section{REFERENCES}

1. Eid HO, Hefny AF, Joshi S, Abu-Zidan FM. Non-traumatic perforation of the small bowel. Afr Health Sci 2008;8:36-39.

2. Chaikof EL. Nontraumatic perforation of the small bowel. Am J Surg 1987;153:355-358.

3. Jain BK, Arora H, Srivastava UK, et al. Insight into the management of non-traumatic perforation of the small intestine. J Infect Dev Ctries 2010;28;4:650-654.

4. Akyildiz HY, Akcan AC, Sözüer E, et al. Unusual causes of intestinal perforation and their surgical treatment. Ulus Travma Acil Cerrahi Derg 2009;15:579-583.

5. Freeman HJ. Spontaneous free perforation of the small intestine in adults. World J Gastroenterol 2014;7:20:9990-9997.

6. Stagnitti F, Coletti M, Corona F, et al. Small intestine tumors: our experience in emergencies. G Chir 2003;24:34-38.

7. Aamer Naseer A, Ahmad S, Naeem M. Primary Repair in Spontaneous Small Bowel Perforations. Ann Pak Inst Med Sci 2009;5:170-173.

8. Ara C, Sogutlu G, Yildiz R, et al. Spontaneous small bowel perforations due to intestinal tuberculosis should not be repaired by simple closure. J Gastrointest Surg 2005;9:514-517.

9. Orringer RD, Coller JA, Veidenheimer MC. Spontaneous free perforation of the small intestine. Dis Colon Rectum 1983;26:323-326.

10. Ara C, Coban S, Kayaalp C, et al. Spontaneous intestinal perforation due to Non-Hodgkin's lymphoma: Evaluation of eight cases. Dig Dis Sci 2007;52:17521756. 